\title{
Monoamine Oxidases Regulate Telencephalic Neural Progenitors in Late Embryonic and Early Postnatal Development
}

\author{
Aiwu Cheng, ${ }^{1}$ Anna L. Scott, ${ }^{2}$ Bruce Ladenheim, ${ }^{3}$ Kevin Chen, ${ }^{2}$ Xin Ouyang, ${ }^{1}$ Justin D. Lathia, ${ }^{1}$ Mohamed Mughal, ${ }^{1}$ \\ Jean Lud Cadet, ${ }^{3}$ Mark P. Mattson, ${ }^{1,4}$ and Jean C. Shih ${ }^{2,5}$ \\ ${ }^{1}$ Laboratory of Neurosciences, National Institute on Aging Intramural Research Program, Baltimore, Maryland 21224, ${ }^{2}$ Department of Pharmacology and \\ Pharmaceutical Sciences, School of Pharmacy, University of Southern California, Los Angeles, California 90089, ${ }^{3}$ Molecular Neuropsychiatry Branch, \\ National Institute on Drug Abuse, Baltimore, Maryland 21224, ${ }^{4}$ Department of Neuroscience, Johns Hopkins University School of Medicine, Baltimore, \\ Maryland 21205, and ${ }^{5}$ Department of Cell and Neurobiology, Keck School of Medicine, University of Southern California, Los Angeles, California 90089
}

\begin{abstract}
Monoamine neurotransmitters play major roles in regulating a range of brain functions in adults and increasing evidence suggests roles for monoamines in brain development. Here we show that mice lacking the monoamine metabolic enzymes MAO A and MAO B (MAO AB-deficient mice) exhibit diminished proliferation of neural stem cells (NSC) in the developing telencephalon beginning in late gestation [embryonic day (E) 17.5], a deficit that persists in neonatal and adult mice. These mice showed significantly increased monoamine levels and anxiety-like behaviors as adults. Assessments of markers of intermediate progenitor cells (IPC) and mitosis showed that NSC in the subventricular zone (SVZ), but not in the ventricular zone, are reduced in MAO AB-deficient mice. A developmental time course of monoamines in frontal cortical tissues revealed increased serotonin levels as early as E14.5, and a further large increase was found between E17.5 and postnatal day 2. Administration of an inhibitor of serotonin synthesis (parachlorophenylalanine) between E14.5 and E19.5 restored the IPC numbers and SVZ thickness, suggesting the role of serotonin in the suppression of IPC proliferation. Studies of neurosphere cultures prepared from the telencephalon at different embryonic and postnatal ages showed that serotonin stimulates proliferation in wild-type, but not in MAO AB-deficient, NSC. Together, these results suggest that a MAO-dependent long-lasting alteration in the proliferation capacity of NSC occurs late in embryonic development and is mediated by serotonin. Our findings reveal novel roles for MAOs and serotonin in the regulation of IPC proliferation in the developing brain.
\end{abstract}

\section{Introduction}

Cerebral cortical neural stem cells (NSC) are located in a proliferative region surrounding the lateral ventricles called the ventricular zone (VZ) and the subventricular zone (SVZ), which emerges superficial to the $\mathrm{VZ}$ at later developmental stage (Angevine et al., 1970). The time course of establishment of embryonic cortical precursor cell diversity has been reviewed recently (Corbin et al., 2008). At the onset of neurogenesis, the initial VZ neuroepithelial precursors (NEP) are thought, at least in part, to transition into a specialized VZ cell type called radial glial cells (RGC). During mid-gestation, RGC generate another specialized cell type, intermediate progenitor cells (IPC), also known as basal progenitor cells (Haubensak et al., 2004; Miyata et

Received April 20, 2010; revised May 31, 2010; accepted June 11, 2010.

This work was supported by the Intramural Research Programs of the National Institute on Aging and National Institute on Drug Abuse, and by National Institute of Mental Health Grants R37 MH39085 (MERIT Award) and R01 MH39085 (to J.C.S.).

Correspondence should be addressed to either Dr. Aiwu Cheng or Dr. Mark P. Mattson, Laboratory of Neurosciences, National Institute on Aging Intramural Research Program, 251 Bayview Boulevard, Baltimore, MD 21224, E-mail: chengai@mail.nih.gov or mattsonm@grc.nia.nih.gov; or Dr. Jean C. Shih, Department of Pharmacology and Pharmaceutical Sciences, School of Pharmacy, University of Southern California, 1985 Zonal Avenue, Los Angeles, CA 90089-1921, E-mail: jcshih@usc.edu.

DOI:10.1523/JNEUROSCI.2037-10.2010

Copyright $\odot 2010$ the authors $\quad$ 0270-6474/10/3010752-11\$15.00/0 al., 2004; Noctor et al., 2004; Götz and Huttner, 2005). Unlike NEP and RGC, which divide at the ventricle surface, IPC divide away from the ventricle and are also known as non-surface dividing cells. The fate of NSC is regulated by a combination of intrinsic factors and extracellular signals from the changing environment/ niche within the developing brain (Temple, 2001; Lathia et al., 2007). However, the signals that regulate NSC fate are poorly understood.

Monoamine (MA) neurotransmitters have been implicated in the regulation of cell proliferation in the developing telencephalon (Cameron et al., 1998). During embryonic development, monoaminergic neurons in the brainstem (serotonergic and noradrenergic) and midbrain (dopaminergic) are generated approximately at the time of telencephalic vesicle formation and their fibers start to innervate the cortex around mid-gestation [embryonic day (E) 16 in rat], which corresponds to the peak time of neurogenesis (Lauder and Bloom, 1974; Coyle and Molliver, 1977; Lidov et al., 1980; Schlumpf et al., 1980; Levitt and Rakic, 1982; Lauder, 1993; Zecevic and Verney, 1995; Berger-Sweeney and Hohmann, 1997; Levitt et al., 1997). Serotonergic fibers are among the earliest axons to reach the developing cerebral cortex (Wallace and Lauder, 1983; Dori et al., 1996) where they can contact dividing cells in the subependymal zone of adult rodent forebrain (Vergé and Calas, 2000). 

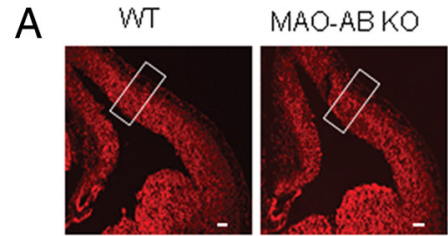

B
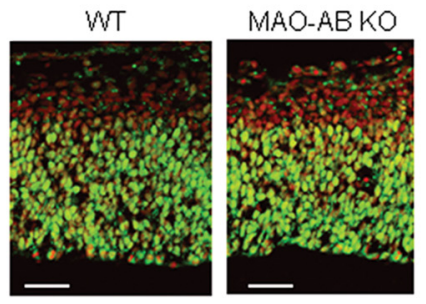

E12.5

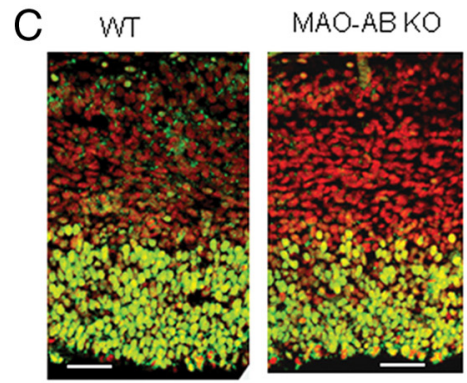

E14.5

Figure 1. Numbers of neural progenitor cells in the germinal zone of the telencephalon are significantly reduced late in embryonic development in MA0 AB-deficient mice. $\boldsymbol{A}-\boldsymbol{D}$, Coronal brain sections from E12.5 (A, B), E14.5 (C), and E17.5 (D) WT and MAO AB KO littermate mice taken from matched sections at the same level of frontal cortex were immunostained with a Sox2 antibody (green) and counterstained with PI (red). Representative higher-magnification confocal images of a slab of the middle telencephalon wall as indicated in $\boldsymbol{A}$ are shown in $\boldsymbol{B}-\boldsymbol{D}$. Scale bar, $50 \mu \mathrm{m}$. $\boldsymbol{E}$, The total number of Sox ${ }^{+}$cells in $100 \mu \mathrm{m}$ slab were quantified and plotted. ${ }^{*} p<0.5$ ( $n=4$ mice).

The regulation of MA neurotransmitters includes their metabolism by the monoamine oxidases (MAO A and MAO B) that degrade serotonin (5-HT), dopamine (DA), and norepinephrine (NE) (Bach et al., 1988, Shih et al., 1999). MAO A prefers 5-HT, $\mathrm{DA}$, and NE, whereas MAO B prefers phenylethylamine (PEA) as substrates. In the absence of MAO A, MAO B oxidizes MAO A's preferred substrates, and vice versa; brain levels of 5-HT, NE, DA, and $\mathrm{PEA}$ are therefore increased to a much greater extent in $\mathrm{MAO}$ $\mathrm{AB}$ double knock-out (MAO AB KO) mice than in either MAO A or MAO B single KO mice (Chen et al., 2004). Here we report that mice lacking both MAO A and MAO B exhibit an abnormality in NSC behavior, characterized by a reduction in IPC in late embryonic and early postnatal development. We further show that this developmental consequence of MAO deficiency results from excessive elevation in the levels of serotonin in the developing cerebral cortex.

\section{Materials and Methods}

Generation of wild-type and MAO AB KO mice. A previous study (Chen et al., 2004) reported that a spontaneous mutation of the MAO A gene in MAO B KO mice resulted in MAO AB KO mice. This mutation caused a nonsense-mediated mRNA decay and resulted in the absence of MAO A transcript, protein, and catalytic activity, and abrogated a DraI restriction site. Since both MAO A and MAO B are on the X chromosome and closely linked, wild-type (WT) and MAOAB KO littermates can be generated by breeding heterozygous $\mathrm{MAO} \mathrm{AB} \mathrm{KO}$ female mice with hemizygous $(-/ \mathrm{y})$ male MAO AB KO or WT $(+/+)$ mice. Littermates of WT and $\mathrm{MAO} \mathrm{AB} \mathrm{KO}$ mice at E12.5, E14.5, and E17.5, and postnatal day $(\mathrm{P})$ $2,7,15$, and 30 were obtained from time-pregnant females. The separa- tion day was designated as E0.5. For genotyping, two complementary PCRs were performed on the genomic DNA from mouse tail biopsies. The first reaction used primers for MAO A (5' GCTTCACAGTGGATTGAT 3' and $5^{\prime}$ CACAAATACGAGCAACCTAC $3^{\prime}$ ) and second reaction used primers for MAO B (5' CTACAAAGCAGATTGCCACGC $3^{\prime}$ and 5' TACCTGACATCAACTGGTCCC $3^{\prime}$ ). The PCR product of the first reaction using MAO A primers ( $\sim 300 \mathrm{bp})$ was digested with the restriction enzyme DraI at $37^{\circ} \mathrm{C}$ for $2 \mathrm{~h}$ or overnight. The amplified DNA from the WT mice with an intact DraI restriction site was cut into 100 and 200 bp products, whereas the DNA amplified from MAO A mutant mice could not be cut by DraI. Samples from heterozygous female MAO A mice therefore exhibit three bands of 100,200, and 300 bps (see supplemental figures, available at www.jneurosci.org as supplemental material). The second PCR generated either $1.5 \mathrm{~kb}$ (MAO B KO) or $291 \mathrm{bp}$ (WT) bands. All animal procedures were approved by the Animal Care and Use Committee of the National Institute on Aging Intramural Research Program and followed National Institutes of Health guidelines.

Histology and immunocytochemistry. Embryos were removed from anesthetized pregnant dams, decapitated, and the heads were immediately fixed in $4 \%$ paraformaldehyde. P2-P7 mice were anesthetized and perfused transcardially with PBS, followed by $4 \%$ paraformaldehyde in $\mathrm{PBS}, \mathrm{pH}$ 7.4. Brains were postfixed for $2 \mathrm{~d}$ and then transferred to a solution of $30 \%$ sucrose in PBS for cryopreservation. Tails from each embryo or postnatal mouse were collected and used as a source of DNA for genotyping. After 3-5 d in cryopreservation solution, cryostat sections were cut in the coronal plane at a thickness of $10 \mu \mathrm{m}$ and collected on Superfrost plus slides (VWR International). Brain sections were processed for immunohistochemistry using the following primary antibodies and dilutions: anti- $\beta_{3}$-tubulin (Tuj1; mouse, 1:250; Sigma), anti- bromodeoxyuridine (BrdU; mouse, 1:250, BD Biosciences), anti-T-brain2 (Tbr2; rabbit; Millipore Bioscience Research Reagents), anti-Sox2 (rabbit, 1:200; Millipore Bioscience Research Reagents), anti-phospho-histone 3 (rabbit, 1:200, Cell Signaling Technology), antiserotonin (1:1000, Sigma), and PCNA (mouse, 1:200, Sigma). Secondary antibodies used and their dilutions were as follows: FITC-conjugated donkey anti-rabbit IgG (BrdU, Tuj1, Sox2; 1:500) and FITC-conjugated donkey anti-mouse IgG (TBR2, PH3; 1:500). For immunofluorescence histochemistry, brain sections were permeabilized and preincubated with blocking solution $(0.2 \%$ Triton X-100, 10\% normal goat serum) in PBS for $30 \mathrm{~min}$ and then incubated overnight with a primary antibody diluted in the same blocking solution at $4^{\circ} \mathrm{C}$. Cells were washed with PBS and incubated with appropriate secondary antibodies diluted in the same blocking solution for $2 \mathrm{~h}$ at room temperature. Sections or coverslips were counterstained with propidium iodide (PI) $(0.02 \%$ PI and 1\% RNase in PBS) for $10 \mathrm{~min}$; they were then washed with PBS and mounted on microscope slides by using a fluorescence anti-fade medium (Vector Laboratories). For BrdU immunohistochemistry, similar procedures were followed, except that the sections were denatured by incubating in a solution of $2 \mathrm{~N} \mathrm{HCl}$ for $45 \mathrm{~min}$ before the primary antibody was added. Using an avidin-biotin-HRP procedure, BrdU immunohistochemistry was performed on free-floating brain sections (30 $\mu \mathrm{m})$. Sections were then incubated in $1 \% \mathrm{H}_{2} \mathrm{O}_{2}$ for 30 min to quench endogenous peroxidase activity. After rinsing with PBS, sections were incubated overnight with primary antibodies at $4^{\circ} \mathrm{C}$, then washed in PBS and further processed using a Vector $\mathrm{ABC}$ elite kit (Vector Laboratories). The sections were further processed by incubation in a solution containing 
A

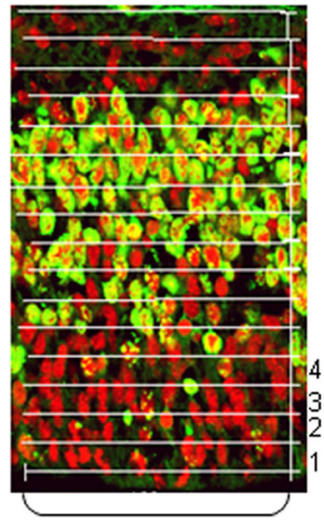

$100 \mu m$
B

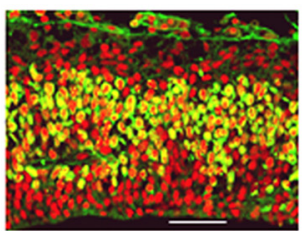

E12.5

C

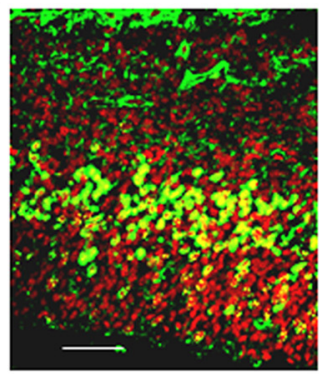

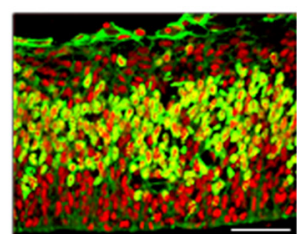

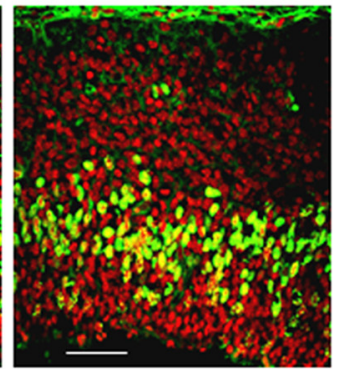

E14.5
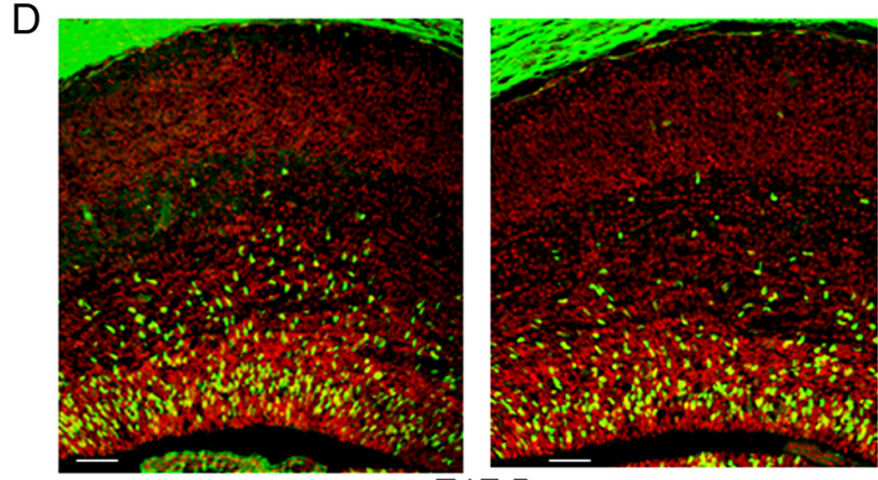

E17.5

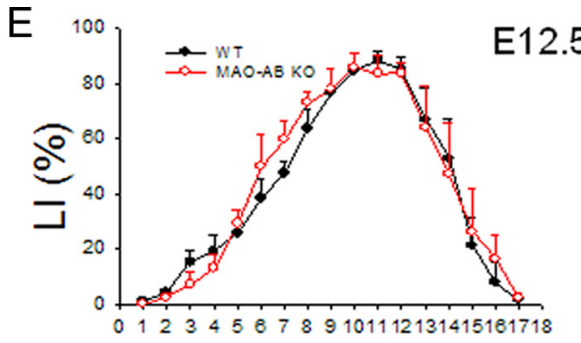

Bin No.

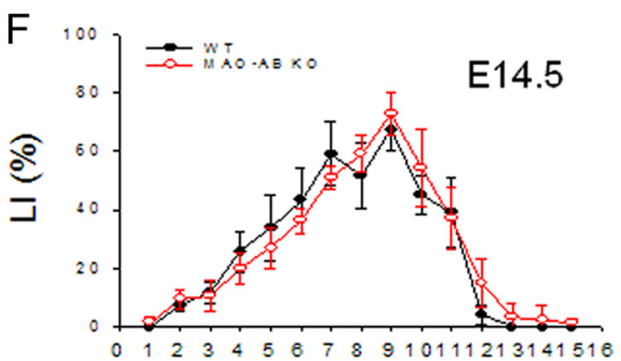

Bin No.

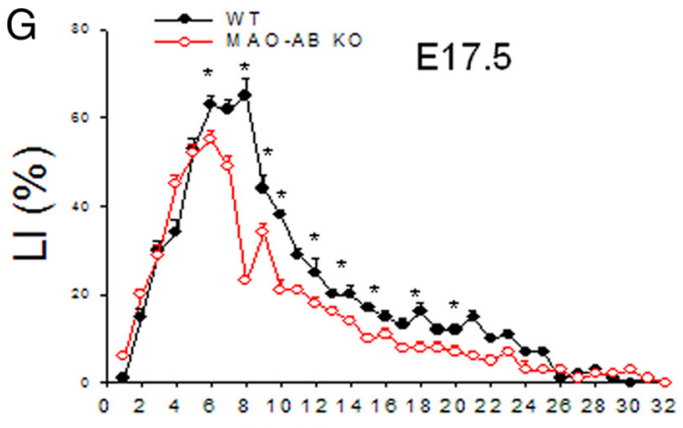

Bin No.

Figure 2. MAOAB-deficient mice exhibit reduced proliferation of neural progenitor cells in the subventricular zone beginning late in embryonic development. Pregnant dams at E12.5, E14.5, and E17.5 were pulse ( $1 \mathrm{~h}$ ) labeled with BrdU and the brain sections were immunostained with BrdU (green) and counterstained with PI (red). $A$, The distribution of the S-phase nuclei (BrdU ${ }^{+}$cells) was analyzed by dividing the cortical VZ/SZV into $10 \mu \mathrm{m}$ bins across the cerebral wall from the ventricle surface. Each bin was $10 \times 100 \mu \mathrm{m}$ in size. BrdU ${ }^{+}$and PI ${ }^{+}$cells in each bin were counted and the $\mathrm{LI}\left(\mathrm{BrdU}^{+} / \mathrm{PI}^{+}\right)$in each bin was calculated. $\boldsymbol{B}-\boldsymbol{D}$, Representative confocal images of a slab of the middle telencephalon wall of WT and MAO AB K0 mice at E12.5 (B), E14.5 (C), and E17.5 (D). Scale bar, $50 \mu \mathrm{m} . \boldsymbol{E}-\mathbf{G}$, The LI was plotted for each of the bins within the analysis areas at E12.5 $(\boldsymbol{E})$, E14.5 $(\boldsymbol{F})$, and E17.5 $(\boldsymbol{B})$. At E17.5, BrdU ${ }^{+}$cells were significantly reduced in the area corresponding to subventricular zone area, but not in the ventricular zone. ${ }^{*} p<0.05$ ( $n=4$ mice)

$0.035 \%$ diaminobenzidine and $0.01 \% \mathrm{H}_{2} \mathrm{O}_{2}$. The developed sections were mounted on Superfrost Plus slides, dehydrated in a graded ethanol series, and immersed in $100 \%$ xylene for $15 \mathrm{~min}$. Sections were then coverslipped in Permount medium (Fisher Scientific).

BrdU administration and cell proliferation assay. Timed-pregnant dams or individual neonatal mice received BrdU by intraperitoneal injection $(50 \mathrm{mg} / \mathrm{kg}$ ) for $1 \mathrm{~h}$ before euthanization. After tissue processing and BrdU immunohistochemistry, the analysis was performed on a sector of the dorsomedial cerebral wall, overlying the medial region of the lateral ventricle and corresponding to the location of the future primary frontal cortex. This sector has as its base a segment of the VZ that is $100 \mu \mathrm{m}$ in its mediolateral dimension. The sector was divided into bins, parallel to the ventricular surface, $10 \mu \mathrm{m}$ in height, and the bins were numbered 1,2,3, and so on from the ventricular surface outward (Takahashi et al., 1992). BrdU-labeled and unlabeled nuclei were scored with respect to their bin location. Nuclei on the boundary between two bins were assigned to the bin closer to the ventricle. Nuclei touching the medial margin, but not those touching the lateral margin, of each bin were included in the analysis. A labeling index (LI; $\mathrm{BrdU}^{+}$cells as a proportion of total cells) was calculated for each bin. The plots of LIs for each bin for each time point is referred as the LI profile for that time point. The average LI for each bin was derived from three nonadjacent sections in each brain (every sixth coronal section from the front to the back of the brain).
For adult neural stem cell measurements, 3-month-old WT and MAO AB KO mice were given three intraperitoneal injections of BrdU $(50 \mathrm{mg} / \mathrm{kg}$ ), each $2 \mathrm{~h}$ apart. This BrdU injection protocol was used to ensure that there were sufficient numbers of cells in SVZ labeled with $\mathrm{BrdU}$, and also ensured that labeled cells did not have enough time to migrate far away from the SVZ, which would complicate the quantification. Mice were transcardially perfused with PBS, followed by $4 \%$ paraformaldehyde in PBS, $\mathrm{pH}$ 7.4. Brains were postfixed overnight, cryoprotected, frozen, and microtome-sectioned in the coronal plane at $30 \mu \mathrm{m}$ thickness. Every sixth section in the forebrain was processed for BrdU immunohistochemistry, and all BrdU-positive cells in the SVZ surrounding the third ventricle in each section (a total of 10 sections for each brain) were counted. The values presented represent the total number of BrdU-positive cells in 10 sections for each brain.

HPLC determination of the levels of 5-HT, NE, DA, and their metabolites in cortical tissues. Timed-pregnant mice were killed at E14.5 and E17.5, and neonatal mice were killed at P2, P7, P15, and P30. Total cortical tissue from embryos and half-brain (one hemisphere) cortical tissue from postnatal mice were quickly removed and immediately frozen at $-80^{\circ} \mathrm{C}$. Brain samples were homogenized in $0.01 \mathrm{M} \mathrm{HClO}_{4}$ and centrifuged at 14,000 g for $15 \mathrm{~min}$. NE, DA, 3,4-dihydroxyphenylacetic acid (DOPAC), homovanillic acid (HVA), 5-HT, and 5-hydroxyindoleacetic acid (5-HIAA) levels were analyzed in the brain extracts using HPLC with 

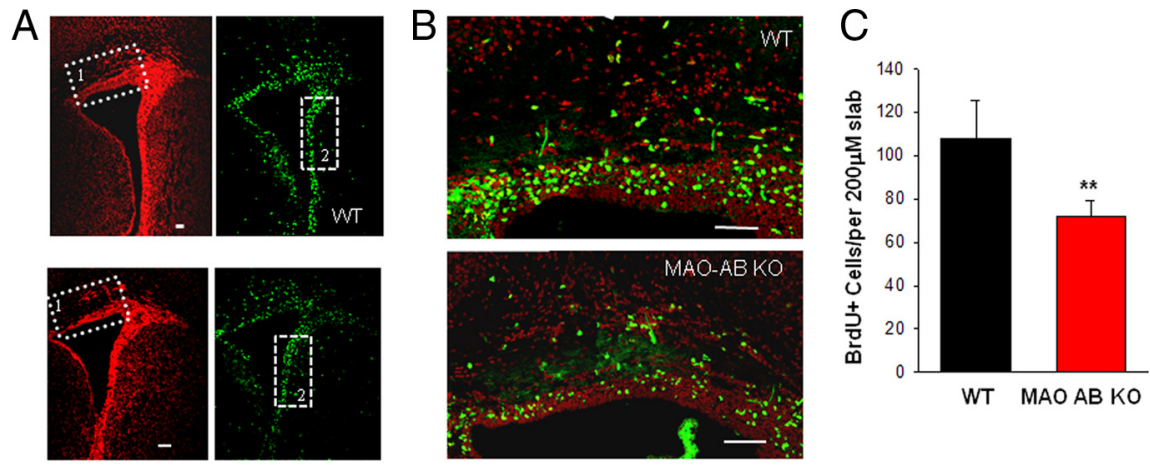

D
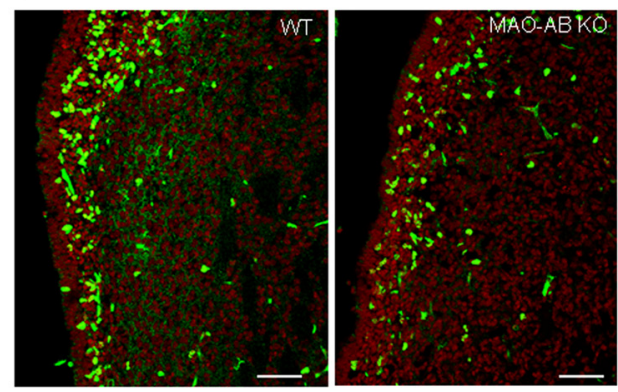

$\mathrm{E}$

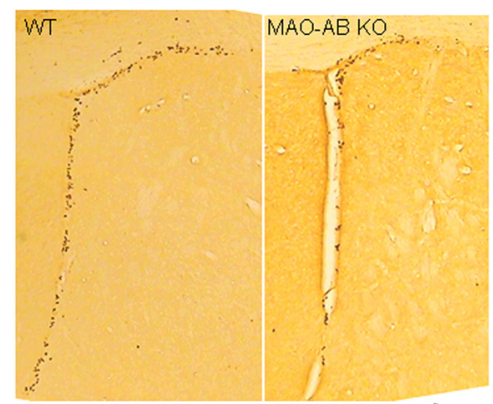

$\mathrm{F}$
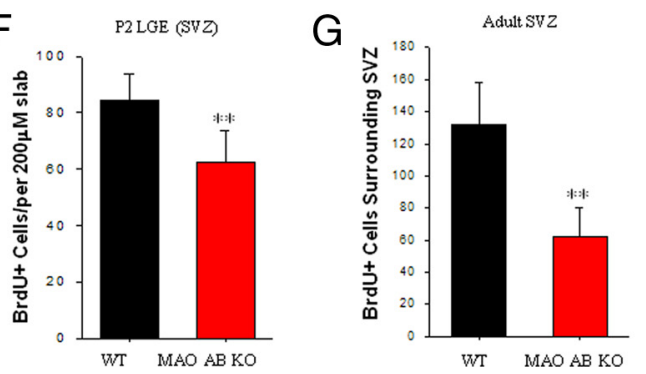

Figure 3. Mice lacking $M A O A$ and $M A O B$ exhibit a sustained reduction in neural progenitor cell proliferation in the subventricular zone during early postnatal and adult life. $\boldsymbol{A}-\boldsymbol{C}$, Neonatal mice (P2) were administrated BrdU and killed $1 \mathrm{~h}$ later. Brain sections were prepared and immunostained with a BrdU antibody (green) and counterstained with PI (red). Representative confocal images of BrdU staining in the SVZ of the frontal cortex in WT and MAO AB KO neonatal mice are presented $(\boldsymbol{A})$ and higher magnification of the dorsal telencephalon SVZ immunostained with BrdU ( $\boldsymbol{A}$, dotted square 1) are shown (B). Scale bar, $50 \mu \mathrm{m}$. $\boldsymbol{C}$, $\mathrm{BrdU}^{+}$cells in a $200 \mu \mathrm{m}$ slab of dorsal telencephalon SVZ were quantified and plotted. ${ }^{* *} p<0.01$ ( $n=4$ mice). D, Higher magnifications of the LGE SVZ immunostained with BrdU antibody (dotted square 2). $E$, BrdU ${ }^{+}$cells in a $200 \mu \mathrm{m}$ slab of LGE SVZ from WT and MAO AB KO mice are shown. Scale bar, $50 \mu \mathrm{m}$. $\boldsymbol{F}$, Results of counts of BrdU-labeled cells in the SVZ of P2 WT and MAO AB K0 mice. ${ }^{* *} p<0.01$ ( $n=4$ mice). G, Adult mice were administered three pulses of BrdU at $2 \mathrm{~h}$ intervals. Every sixth section in the forebrain was processed for BrdU immunohistochemistry. All BrdU-positive cells in the SVZ surrounding the lateral ventricle in each section were counted for each brain. The values represent the total number of BrdU-positive cells at designated level for each brain. ${ }^{* *} p<0.01$ ( $n=4$ mice).

electrochemical detection, as described previously (Ladenheim et al., 2000; Krasnova et al., 2007; Martin et al., 2007). The protein concentrations were determined using the BCA kit (Pierce). Monoamine levels were calculated as $\mathrm{pg} / \mathrm{mg}$ protein.

For the parachlorophenylalanine (PCPA) injection experiment, pregnant mice received a single injection each day from E14.5 to E19.5 of 300 (E14.5), 200 (E15.5, E16.5), and $100 \mathrm{mg} / \mathrm{kg}$ (E7.5, E18.5) PCPA or vehicle. Some of the mice at $\mathrm{P} 0-\mathrm{P} 1$ received BrdU by intraperitoneal injection $(50 \mathrm{mg} / \mathrm{kg})$ for $1 \mathrm{~h}$ and then their brains were processed for immunohistochemistry; other mice were killed directly and cortical tissue was collected for HPLC determination of 5-HT levels.

Neurosphere cultures and analysis. Neurosphere (NS) cultures were prepared from E14.5, E17.5 and P2 mouse dorsal telencephalon, as described previously (Cheng et al., 2007, Lathia et al., 2008). Briefly, pregnant mice were killed, embryo brains were removed, and the cortical cerebral wall was dissected in sterile HBSS. For neonatal mice, the brains were removed from skulls and then washed in sterile HBSS. Then brains were placed dorsal side up on sterilized filter paper and sliced in the coronal plane with a razor into 5 sections. The brain slices were transferred to a sterile cell culture dish with a small volume of HBSS for specific removal of the region surrounding the later ventricles. The corresponding tail of each embryo or neonatal mouse was collected for genomic DNA extraction and genotyping. The brain tissue from each embryo or neonatal mouse was incubated in $0.05 \%$ trypsin-EDTA for $15 \mathrm{~min}$ at $37^{\circ} \mathrm{C}$ and then transferred to NS culture medium consisting of DMEM/F12 (1:1), supplemented with B-27 and $30 \mathrm{ng} / \mathrm{ml}$ basic fibroblast growth factor (BD Biosciences) and $30 \mathrm{ng} / \mathrm{ml}$ epidermal growth factor (Invitrogen), and were dissociated by titration using a fire-polished Pasteur pipette. The cells were cultured at a density of 10,000 cells $/ \mathrm{ml}$ in uncoated plastic culture flasks for embryonic tissue, and at a density of 50,000 cells $/ \mathrm{ml}$ for neonatal tissue. After NS had grown for 4-5 d in culture, 10-20 random images were captured on a Leica inverted microscope with a $10 \times$ objective lens for primary neurosphere diameter measurements. Approximately 150-200 neurospheres were analyzed for each culture. For neurosphere clonal analysis, primary NS were dissociated using the NeuroCult cell dissociation kit (StemCell Technologies) and plated into 96-well plates (Nunc) at 2000 cells per well in $200 \mu \mathrm{l}$ of NS culture medium. After 5-7 d in culture, pictures of neurospheres in eight wells per experimental condition were taken using a digital camera. Images were then analyzed using Adobe Photoshop or NIH ImageJ software for both NS number and diameter. Neurospheres prepared from at least three littermates were analyzed at each developmental stage.

MAO A and B catalytic activity assays. P2 neurospheres were collected by centrifugation and homogenized in assay buffer (50 $\mathrm{mm}$ sodium phosphate buffer, pH 7.4). Samples were incubated for $20 \mathrm{~min}$ at $37^{\circ} \mathrm{C}$ with $100 \mu \mathrm{M}{ }^{14} \mathrm{C}$ labeled serotonin for measurement of MAO A activity or $10 \mu \mathrm{M}{ }^{14} \mathrm{C}$-labeled PEA (PerkinElmer Life and Analytical Sciences) for measurement of MAO B activity. Reactions were terminated by addition of $100 \mu$ lof $6 \mathrm{~N} \mathrm{HCl}$, and reaction products were extracted with ethylacetate/benzene 1:1 for MAO A or toluene for MAO B and centrifuged for $7 \mathrm{~min}$. The organic phase containing the reaction product was extracted and its radioactivity measured by liquid scintillation spectroscopy, as reported previously (Geha et al., 2001). Protein concentrations were measured to calculate the specific catalytic activity.

\section{Results}

NSC proliferation is reduced in the dorsal telencephalon of MAO AB KO mice during late embryonic and early postnatal development

MAO AB KO mice were generated by a spontaneous mutation in a MAO A gene in a colony of MAO B KO mice. This mutation (A863T) in exon 8 of the MAO A gene introduced a premature stop codon and caused a nonsense-mediated mRNA decay, resulting in the absence of a MAO A transcript, protein, and catalytic activity in MAO B KO mice (Chen et al., 2004). Adult MAO $\mathrm{AB}$ KO mice exhibit elevated levels of monoamines (5-HT, NE, 
and DA) and anxiety-like behaviors (Chen et al., 2004). To determine whether and when NSCs are altered during brain development in MAO $\mathrm{AB} \mathrm{KO}$ mice, we collected the brains of littermate WT and MAO AB KO mice at E12.5, E14.5, E17.5, and P2. We immunostained coronal sections of the telencephalon with an antibody against Sox2, a transcription factor expressed only in self-renewing NSC (Zappone et al., 2000; Cai et al., 2002). At E12.5 and E14.5, Sox $2^{+}$cells demark a clear germinal zone (VZ/SVZ) and there is no apparent difference between WT and MAO AB KO mice (Fig. $1 A-C$ ). At E17.5, some Sox ${ }^{+}$cells are dispersed from the top of a condensed germinal zone (Fig. $1 D)$. The Sox $2^{+}$cells were quantified in a $100-\mu \mathrm{m}$-wide slab oriented perpendicular to the developing cortical wall and at the same rostral-caudal level of frontal cortex in all brains (Fig. $1 A, D$ ). The results showed that there are $\sim 25 \%$ fewer Sox ${ }^{+}$cells in MAO AB KO mice compared with WT mice at E17.5, but no difference in numbers of Sox ${ }^{+}$cells at E12.5 or E14.5 (Fig. 1E).

To further characterize the perturbation of NSC proliferation in MAO AB KO mice, we pulse-labeled developing embryos with the DNA precursor BrdU by administering BrdU to pregnant dams carrying E12.5, E14.5, or E17.5 embryos. One hour after the BrdU pulse, the embryos were removed and brain sections were prepared and immunostained with a BrdU antibody. When the BrdU LI was plotted as a function of distance from the lateral ventricular border (i.e., for each bin) (Fig. $2 A$ ), we found that the interkinetic nuclear migration, a hallmark of ventricular zone NSC (Angevine et al., 1970; Loulier et al., 2009), was preserved in MAO $\mathrm{AB} \mathrm{KO}$ embryos (Fig. 2B-D). Thus, the BrdU LI was higher in bins representing the $S$ phase zone (bins 9-12 at E12.5, bins 7-10 at E14.5, and bins 5-8 at E17.5) (Fig. 2 $E-G$ ). There were no apparent differences in $\mathrm{BrdU}^{+}$cell number, distribution patterns, or LI between WT and $\mathrm{MAO} \mathrm{AB} \mathrm{KO}$ embryos at E12.5 or E14.5. In contrast, at E17.5, there is a significant reduction of $\mathrm{BrdU}^{+}$cells (Fig. $2 D$ ) and LI (Fig. 2G) in MAO AB KO mice compared with WT mice, particularly away from the ventricular wall (bins $8-22$ ), which corresponds to the SVZ. At P2, the SVZ in the dorsal telencephalon is thinner in MAO AB KO mice (Fig. $3 A$, boxed area 1) compared with $\mathrm{WT}$ mice, and $\mathrm{BrdU}^{+}$cells are significantly reduced in MAO AB KO mice (Fig. $3 B, C$ ). We also examined the $\mathrm{BrdU}^{+}$cells in the $\mathrm{SVZ}$ of lateral ganglionic eminence (LGE) region in $\mathrm{P} 2$ mice (Fig. $3 A$, boxed area 2 , and $D, F$ ) and in the striatal region in adult mice (Fig. $3 E, G$ ). Numbers of

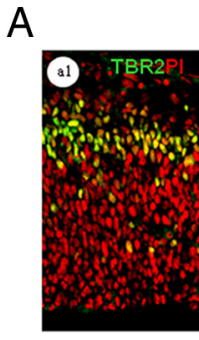

E12.5

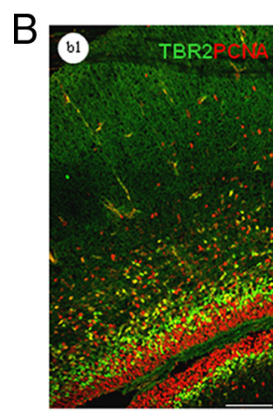

D

E
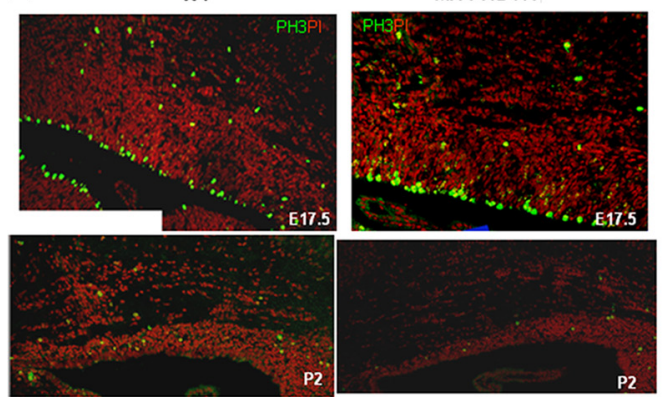

E17.5

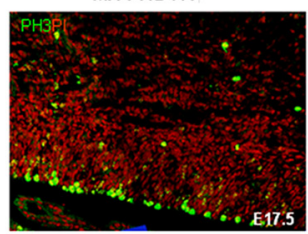

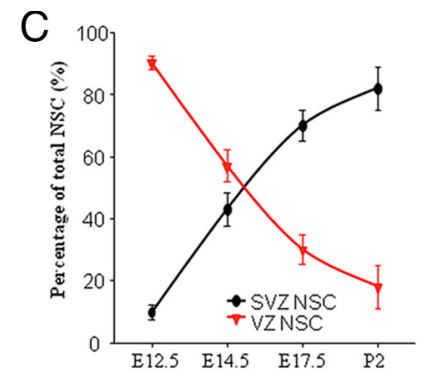
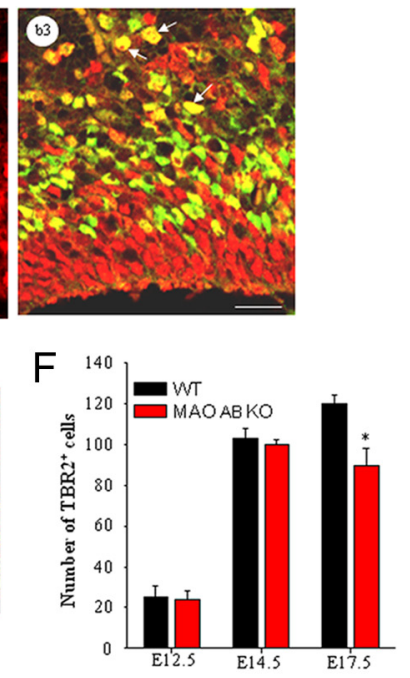

G

$\mathrm{G}$

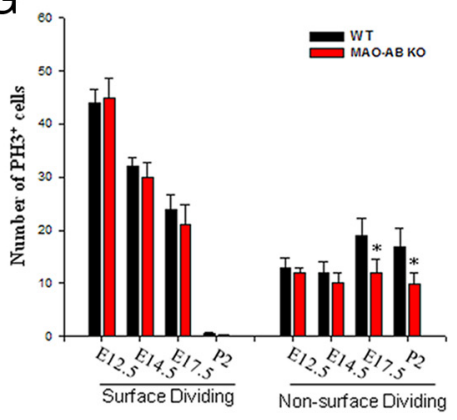

Figure 4. $I P C$, but not RGCs in VZ, are specifically affected in MAO AB KO mice. $A$, Representative confocal images of TBR2 immunostaining (green) in brain sections from E12.5 (a1), E14.5 (a2), and E17.5 (a3) WT mice; the sections are counterstained with PI (red). TBR2 is a marker for IPC in the SVZ of the dorsal telencephalon. $\boldsymbol{B}$, Representative confocal images of TBR2 (green) and PCNA (red) double immunostaining in WT E17.5 frontal cortex (b1) and higher magnification (b2, PCNA staining; $\boldsymbol{b} 3$, merged image of PCNA and TBR2 staining) showed that nearly all TBR2 ${ }^{+}$cells are also PCNA ${ }^{+}$. Arrows, Representative cells. $\boldsymbol{C}$, The percentage of TBR2 ${ }^{+} / S_{0 \times 2}{ }^{+}$cells in a $100 \mu \mathrm{m}$ slab was plotted for different development stages. VZ cells gradually decrease in numbers, whereas the SVZ expands as development proceeds. $\boldsymbol{D}, \boldsymbol{E}$, Coronal sections of E17.5 and P2 frontal cortex of WT and MAO AB KO mice immunostained with anti-TBR2 ( $\boldsymbol{D}$, green) or anti-PH3 ( $\boldsymbol{E}$, green; a marker for cell entry into mitosis). Sections were counterstained with $\mathrm{PI}(\boldsymbol{D}, \boldsymbol{E}$, red). Note that $\mathrm{PH} 3$ immunostaining clearly demonstrates two types of dividing cells: surface dividing and non-surface dividing. $\boldsymbol{F}$, Numbers of non-surface dividing TBR2 ${ }^{+}$cells in the dorsal telencephalon at the indicated embryonic developmental stages. $\mathbf{G}$, Numbers of surface dividing and non-surface dividing $\mathrm{PH}{ }^{+}{ }^{+}$cells at the indicated embryonic and postnatal developmental stages. Note that numbers of non-surface dividing TBR2 ${ }^{+}$cells and PH3 ${ }^{+}$cells are significantly reduced in E17.5 and P2 MAO ABK0 mice compared with WT mice. ${ }^{*} p<0.05$ ( $n=4$ mice).

$\mathrm{BrdU}^{+}$cells in the later proliferative zones of $\mathrm{P} 2$ and adult $\mathrm{MAO}$ $\mathrm{AB} \mathrm{KO}$ mice were also significantly lower compared with WT mice (Fig. 3D-G). Moreover, cell death in the pallium of E17.5 and P2 mice were measured using the TUNEL method. The incidence of cell death was very low at both E17.5 and P2, with no significant differences between WT and MAO AB KO mice (supplemental Fig. S1, available at www.jneurosci.org as supplemen- 

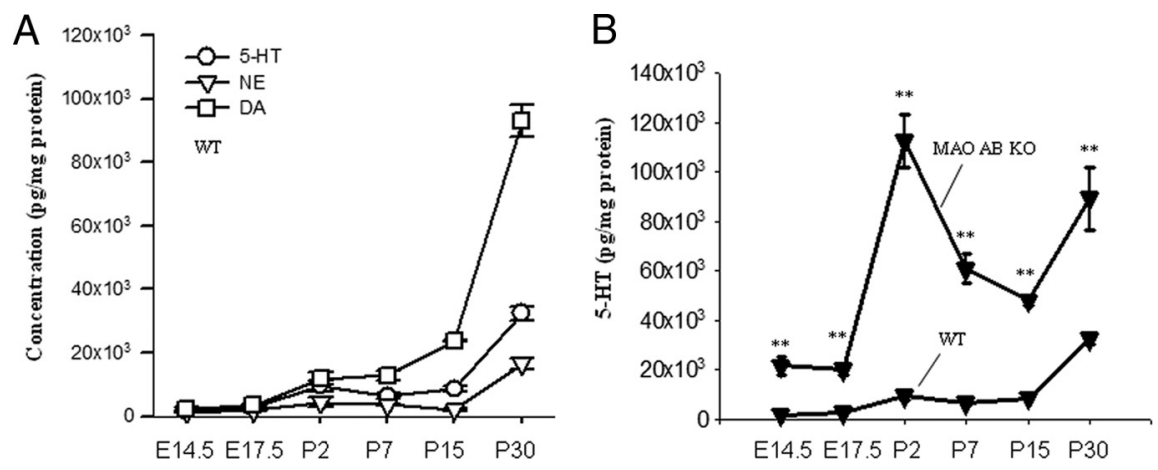

Figure 5. Cortical serotonin levels increase markedly during late embryonic and early postnatal brain development. $\boldsymbol{A}$, Developmental change (E14.5-P30) in levels of 5-HT, DA, and NE in the cortex of WT mice. $\boldsymbol{B}$, There is a dramatic increase in levels of 5-HT in the cerebral cortex of MAO AB KO mice compared with WT mice. Values are expressed as pg/mg protein and represent the mean \pm SEM. ${ }^{* *} p<0.001$ ( $n=3-5$ mice).

tal material). Collectively, the data show that NSC number and proliferation rate in the telencephalon and LGE of MAO AB KO mice are significantly reduced in late embryonic and early postnatal development, an alteration which persists in adults.

\section{MAO AB KO mice exhibit a selective reduction of IPC in the SVZ}

As described in the introduction, different subpopulations of neural progenitors in the telencephalic proliferative zone are generated as cortical development proceeds. Both NEP and RGC in VZ exhibit interkinetic nuclear migration with $S$ phase at the pial side and mitosis at the ventricular surface (surface dividing). IPC, which are generated from RGC at early and mid-gestational stages, comprise a major cell population in the SVZ. IPC divide away from the ventricle and thus they are also known as nonsurface dividing cells. A study by Englund et al. (2005) found that transition of RGC to IPC is associated with the expression of TBR2, a T-domain transcription factor (Bulfone et al., 1999). We found that TBR2-immunoreactive cells are located above and intermingled with $\mathrm{VZ}$ cells in the dorsal telencephalon at E12.5, E14.5, and E17.5 (Fig. 4A). Double staining with TBR2 and PCNA [a marker of proliferating cells (Iatropoulos and Williams, 1996)], showed that the vast majority of $\mathrm{TBR}^{+}{ }^{+}$cells $(97 \% \pm$ $2.1 \%, n=3$ ) in the frontal cortex of E17.5 wild-type mice are actively dividing $\mathrm{PCNA}^{+}$cells (Fig. $4 \mathrm{~B}$ ), indicating they are progenitors and not postmitotic. Consistent with previous reports (Englund et al., 2005), the percentage of $\mathrm{TBR}^{+} /$Sox $2^{+}$cells in the proliferative zone gradually increases from E12.5-P2 coincident with a decrease of VZ cells (Fig. 4A,C). TBR2 ${ }^{+}$cells are significantly reduced in the telencephalic germinal zone of MAO $\mathrm{AB}$ KO mice at E17.5, but not at E12.5 or E14.5, compared with WT mice (Fig. 4D,F). We next assessed the surface and nonsurface dividing cells by immunostaining embryonic and early postnatal brain sections from WT and MAO AB KO mice using an antibody against phosphohistone $\mathrm{H} 3$ (PH3), a marker for cell entry into mitosis. $\mathrm{PH}^{+}{ }^{+}$cells clearly exhibited two types of divisions, surface dividing and non-surface dividing, in the frontal telencephalon (Fig. 4E). Cell-count data demonstrated that surface dividing cells are gradually decreased as brain development proceeds and are largely absent in the postnatal telencephalon. Comparison of MAO AB KO and WT mice showed that there are no alterations in surface-dividing $\mathrm{PH}^{+}$cells, whereas nonsurface $\mathrm{PH}_{3}{ }^{+}$cells are significantly reduced in E17.5 and P2 in MAO AB KO mice (Fig. 4G). Therefore, reduction of NSC numbers and proliferation rate in the telencephalon of MAO $\mathrm{AB} \mathrm{KO}$ mice occurs mainly as the result of an effect on IPC, and not earlier RGCs.

A surge in serotonin levels occurs in the telencephalon during late embryonic and early postnatal development

We have previously shown (Chen et al., 2004) that MA neurotransmitters, particularly 5-HT, are significantly increased in the brain of adult MAOAB KO mice compared with WT mice. To study the susceptibility of cortical IPC to the alteration of MAs in MAO AB KO mice, it is essential to establish the developmental changes of 5-HT, DA, and NE in the cerebral cortex of both WT and MAO AB KO mice. Our HPLC analysis data demonstrate that, in WT mice, 5-HT, DA, and NE levels exhibit similar maturation pattern during brain development: low levels in embryonic stages, significant increases during early postnatal development (P2-P15), followed by another significant and rapid increase after P15 (Fig. 5A; Table 1). There were no significant differences in DA levels of WT and MAO AB KO mice at any stage of cortical development, whereas NE levels rose to a significantly higher level at P30 in MAO AB KO mice compared with WT mice (Table 1).

In contrast to DA and NE, 5-HT levels were increased significantly and dramatically during late embryonic and early postnatal brain development (7.5-fold at E17.5 and 12-fold at P2) in MAO AB KO mice compared with WT mice. 5-HT levels remained elevated in MAOAB KO mice compared with WT mice ( 9-, $\sim 4$-, and $\sim 3$-fold elevations at P7, P15, and P30, respectively). Therefore, 5-HT levels in MAO AB KO mice during brain development exhibit a distinct pattern with a huge surge during late embryonic and early postnatal stages (Fig. 5B, Table 1). Furthermore, immunostaining of brain sections with a serotonin antibody showed that the increase in serotonin levels was not limited to the telencephalon area. We found that there was also a dramatic increase in the levels of serotonin in the LGE (supplemental Fig. S2, available at www.jneurosci.org as supplemental material). Consistent with the notion that MAO is a key enzyme catalyzing the oxidative deamination of monoamines, the 5-HT metabolite 5-HIAA and the DA metabolites DOPAC and HVA were greatly reduced in $\mathrm{MAO} \mathrm{AB} \mathrm{KO}$ mice at each developmental stage compared with WT mice (Table 1).

\section{An excess of cortical serotonin has a causal role in the perturbed IPC proliferation and cortical development deficit in MAO AB KO mice}

Consistent with in vivo observations, we found that NSC self renewal ability is also disturbed in a developmental stage-specific manner in NSC when neurosphere cultures derived from the dorsal telencephalon of MAO AB KO mice were compared with those from WT mice (Fig. $6 A-C$ ). The size of neurospheres at E17.5 and P2 of MAO AB KO mice were significantly smaller than the age-matched neurospheres from WT mice. No difference was found at E14.5. Neurosphere-forming assays showed that significantly fewer neurospheres formed from $\mathrm{P} 2 \mathrm{MAO} \mathrm{AB} \mathrm{KO}$ mice ( $\sim 30 \%$ decrease) compared with P2 WT controls (Fig. 6A-C). These data suggested that NSC self-renewal ability is impaired in vitro in $\mathrm{MAO} \mathrm{AB} \mathrm{KO}$ mice in late embryonic and early postnatal developmental stages. 
Table 1. Levels of 5-HT, NE, and DA and their metabolites 5HIAA, DOPAC, and HVA in different developmental stages of cortex in WT and MAO AB-KO mice

\begin{tabular}{|c|c|c|c|c|c|c|}
\hline & $\mathrm{E} 14.5(n=4)$ & $\mathrm{E} 17.5(n=5)$ & $\mathrm{P} 2(n=5)$ & P7 $(n=3)$ & $\mathrm{P} 15(n=3)$ & $\mathrm{P} 30(n=5)$ \\
\hline \multicolumn{7}{|l|}{ 5-HT } \\
\hline WT & $1731.2 \pm 458.9$ & $2674.3 \pm 446.1$ & $9473.4 \pm 1571.2$ & $6421.72 \pm 693.38$ & $8566.5 \pm 691.9$ & $32390.9 \pm 2134.0$ \\
\hline KO & $11612.7 \pm 3649.9^{*}$ & $20057.1 \pm 2219.5^{*}$ & $112764.4 \pm 10807.9^{*}$ & $60857.3 \pm 5917.2^{*}$ & $38627.6 \pm 573.8^{*}$ & $89385.7 \pm 12703.3^{*}$ \\
\hline \multicolumn{7}{|c|}{ (1) } \\
\hline WT & $1278.0 \pm 182.9$ & $1862.90 \pm 322.33$ & $4325.7 \pm 1434.5$ & $3555.13 \pm 314.11$ & $2133.13 \pm 483.62$ & $16419.1 \pm 1762.0$ \\
\hline KO & $1262.3 \pm 143.8$ & $1153.85 \pm 145.66$ & $4494.8 \pm 237.4$ & $3023.95 \pm 79.46$ & $2089.07 \pm 127.15$ & $25899.5 \pm 3117.0^{*}$ \\
\hline \multicolumn{7}{|l|}{ DA } \\
\hline WT & $2363.4 \pm 714.4$ & $2411.99 \pm 272.75$ & $11838.2 \pm 1952.2$ & $12813.67 \pm 1608.02$ & $23674.22 \pm 277.66$ & $92998.0 \pm 4948.7$ \\
\hline KO & $1394.9 \pm 398.3$ & $1984.57 \pm 271.43$ & $13182.8 \pm 801.5$ & $12979.23 \pm 4089.02$ & $16877.84 \pm 2375.94$ & $96562.6 \pm 17414.6$ \\
\hline \multicolumn{7}{|l|}{ 5HIAA } \\
\hline WT & $2036.0 \pm 339.8$ & $1578.17 \pm 238.95$ & $5457.0 \pm 732.0$ & $3339.66 \pm 238.00$ & $7925.64 \pm 628.68$ & $16165.9 \pm 1178.8$ \\
\hline KO & $324.5 \pm 163.1^{*}$ & $169.10 \pm 108.87^{*}$ & $727.7 \pm 247.9^{*}$ & $97.75 \pm 15.07^{*}$ & $9.80 \pm 1.04^{*}$ & $2077.9 \pm 1577.9^{*}$ \\
\hline \multicolumn{7}{|l|}{ DOPAC } \\
\hline WT & - & - & $1505.7 \pm 320.1$ & $1900.15 \pm 164.40$ & $4115.55 \pm 501.90$ & $8424.1 \pm 1043.3$ \\
\hline KO & - & - & $0^{*}$ & $0^{*}$ & $0^{*}$ & $0^{*}$ \\
\hline \multicolumn{7}{|l|}{ HVA } \\
\hline WT & - & - & $1568.5 \pm 322.0$ & $3154.31 \pm 731.88$ & $10736.46 \pm 493.30$ & \\
\hline KO & - & - & $0^{*}$ & $0^{*}$ & $0^{*}$ & \\
\hline
\end{tabular}

Values are expressed in $\mathrm{pg} / \mathrm{mg}$ protein and represent the mean \pm SEM $\left(n=4-5\right.$ mice). ${ }^{*} p<0.001$.

We also found that MAO A activity, but not MAO B activity, can be detected in WT E12.5 neurospheres, and its levels were increased at E15.5 with a further increase at P2 (Fig. 6D). However, MAOA activity per se is not required for the self renewal of NSC in neurospheres because treatment of $\mathrm{P} 2$ neurospheres from WT mice with the MAO A inhibitor clorgyline, at a concentration that completely blocks MAOA activity (Fig. 6E), did not affect neurosphere size or the frequency of neurosphere formation (Fig. $6 F, G)$. Thus, the decreased neurosphere size and number may not be the direct effect of MAOA deficiency.

We next determined whether serotonin would differentially affect the growth of neurospheres derived from the SVZ of the dorsal telencephalon of P2 WT and MAO AB KO mice. Treatment with serotonin at low concentrations $(10-100 \mathrm{ng} / \mathrm{ml}) \mathrm{re}-$ sulted in a concentration-dependent increase in the number of neurospheres formed from P2 WT NSC; further increases in 5-HT concentration $(1000 \mathrm{ng} / \mathrm{ml})$ inhibited neurosphere growth (Fig. $6 H$ ). Serotonin did not affect neurosphere formation in NSC from P2 MAO AB KO mice, suggesting that P2 NSC lacking $\mathrm{MAOs}$ are unresponsive to the stimulatory effect of serotonin (Fig. $6 H$ ). In contrast, we found that there was no difference in E12.5 NS size between WT and MAO AB KO and no abolishment of the stimulatory effect of serotonin in E12.5 NS from MAO AB KO mice compared with NS from WT mice (supplemental Fig. S3, available at www.jneurosci.org as supplemental material). Intriguingly, we found that serotonin receptor subtype serotonin receptor 1A (5-HT1A) is detectable in both E12.5 and E17.5 NS, with levels of this receptor being similar in E12.5 WT and MAO $\mathrm{AB}$ KO NS. In E17.5 NS, the levels of 5-HT1A expression were greater in WT NS compared with MAO AB KO NS (supplemental Fig. S3, available at www.jneurosci.org as supplemental material). Collectively, these data suggest that IPC self-renewal potential is modified by the developmental effects of serotonin in vivo during late embryonic and early postnatal development.

The data above suggested that very high and sustained levels of serotonin can impair the self-renewal potential of IPC, thereby resulting in depletion of the IPC pool in neonatal MAO AB KO mice. To further test this possibility, we administered PCPA, an inhibitor of serotonin synthesis, to pregnant $\mathrm{MAO} \mathrm{AB} \mathrm{KO}$ mice at E14.5-E19.5. HPLC analysis of 5-HT levels in neonatal mouse telencephalon demonstrated that the huge increase of 5-HT levels was abrogated by PCPA treatment, whereas levels of DA and NE were unaffected (Fig. 7A), Serotonin immunostaining confirmed that 5 -HT levels in the cerebral cortex were greatly increased in $\mathrm{MAO} \mathrm{AB} \mathrm{KO}$ mice, and that PCPA treatment markedly reduced 5-HT levels (Fig. 7B). Examination of brain sections stained with cresyl violet revealed the expected cortical dysgenesis in the MAO $\mathrm{AB} \mathrm{KO}$ mice and showed that treatment with PCPA during late embryonic development abolished the cortical development defect (Fig. $7 C$ ). PCPA treatment resulted in a significant increase in the thickness of the SVZ in MAO AB KO mice (Fig. 7C,D). Furthermore, we found that the deficit of TBR2 ${ }^{+}$cells in the SVZ of the dorsal telencephalon is also ameliorated by treatment of E14.5-E19.5 MAO AB KO mice with PCPA (Fig. $7 E, F$ ).

\section{Discussion}

Brain development is regulated by a combination of cell autonomous factors and extracellular signals in a rapidly changing cellular and molecular environment. Our findings suggest that MAOs, the major enzymes involved in monoamine metabolism, influence the behavior of NSC during late embryonic and early postnatal development of the telencephalon in mice. MAO AB $\mathrm{KO}$ mice exhibited significant reductions in Sox ${ }^{+}$cells and $\mathrm{TBR}^{+}{ }^{+}$cells in the SVZ of the dorsal telencephalon, which is evident at E17.5 and P2, but not at earlier developmental stages.

Therefore, MAO AB-deficient mice exhibit unique developmental phenotypes with the reduction of particular NSC subtype (IPC) at time-specific manner. The findings reveal a novel role for MAOs in the regulation of telencephalic IPC before their differentiation, beginning in late embryonic brain development.

There is a wealth of literature on 5-HT as a developmental factor and morphogen, and as a molecule that impacts progenitor proliferation. In most cases, 5 -HT appears to stimulate progenitor proliferation. For example, it was reported that serotonin acting on 5-HT receptors can modulate the proliferation of cortical progenitors in the adult brain; administration of a 5-HT1A agonist increased in the number of progenitor cells in the subventricular zone and dentate gyrus of the hippocampus (Banasr et al., 2001, 2004). In addition, pharmacological serotonin depletion or serotoninergic denervation resulted in a large reduction of precursor cell proliferation in adult rodents (Brezun and Daszuta, 1999; Gould, 1999; Santarelli et al., 2003; Lau et al., 
A
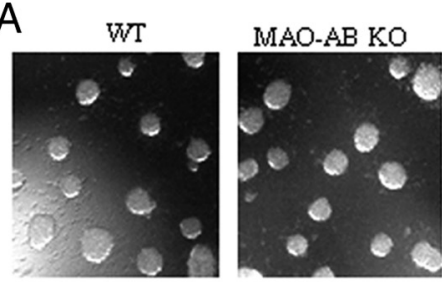

E14.5

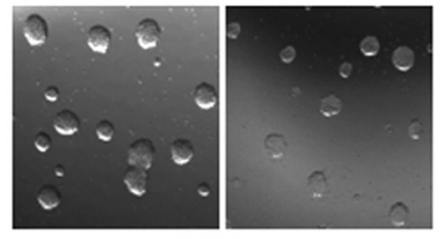

E17.5

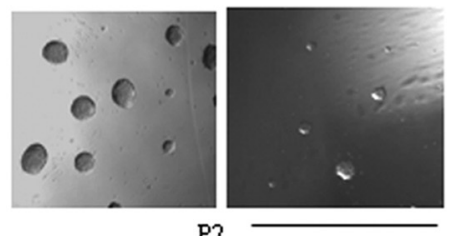

P2

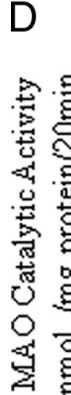

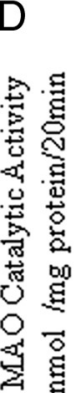

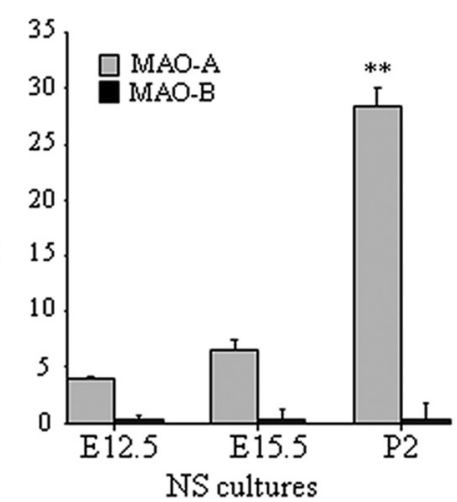

B

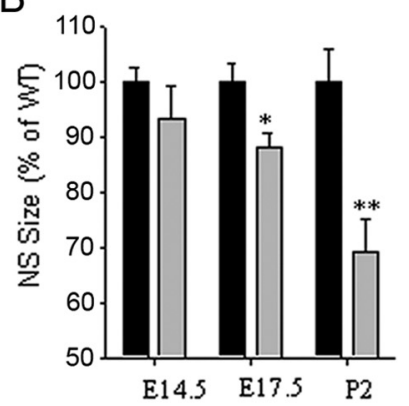

C

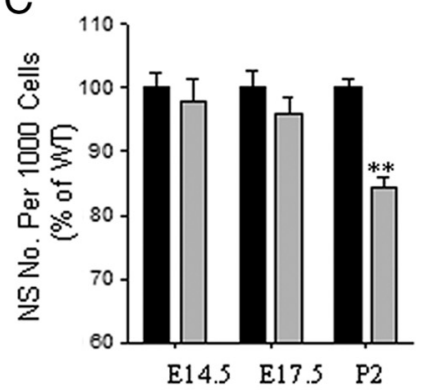

E

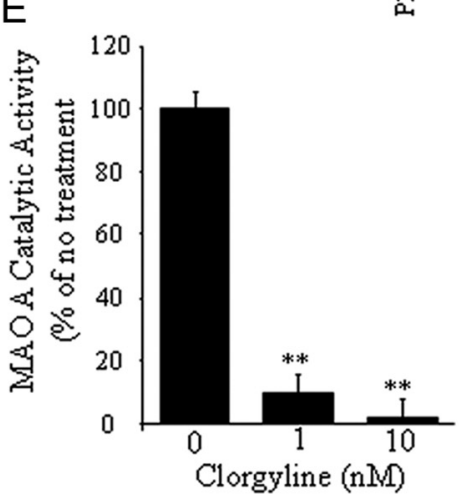

F

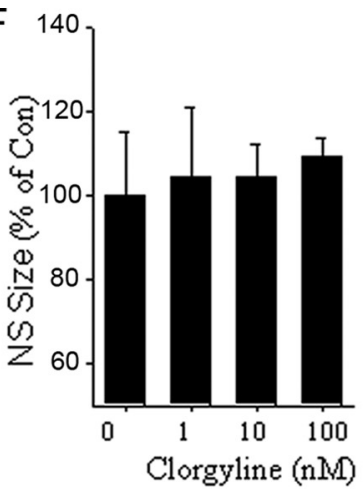

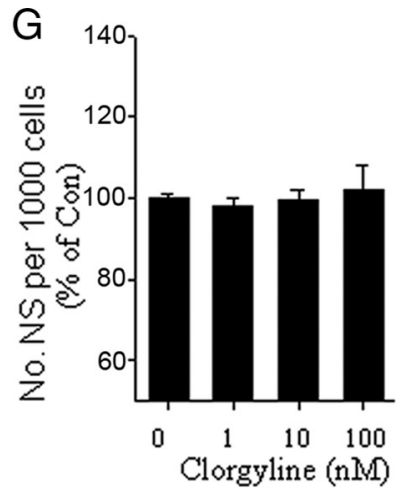

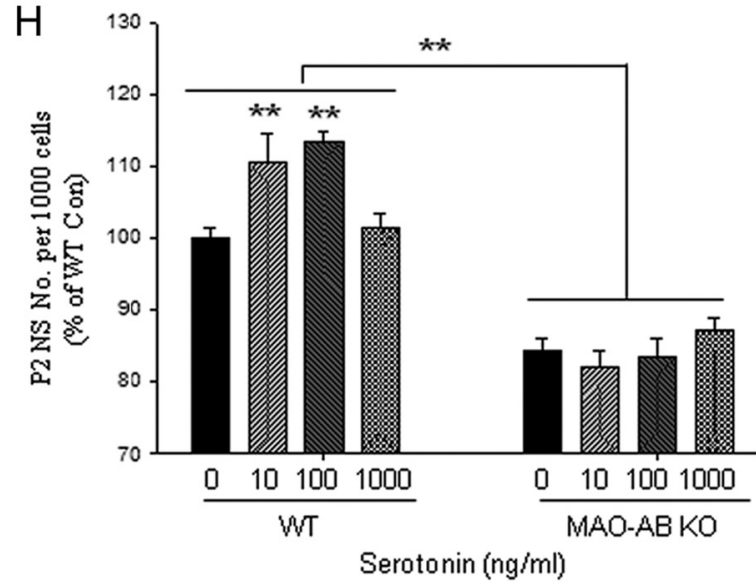

Figure 6. Evidence that MAO activity exerts a long-lasting effect on the proliferative capacity of NSC in the developing telencephalon. $\boldsymbol{A}$, Images of neurospheres in cultures prepared from the VZ/SVZ of the dorsal telencephalon of E14.5, E17.5, and P2 MAO AB KO and WT littermate mice. Scale bar, $1.0 \mathrm{~mm}$. $\boldsymbol{B}, \boldsymbol{C}$, Sizes of first generation $(\boldsymbol{B})$ and second generation $(\boldsymbol{C})$ neurospheres established from telencephalic tissues of WT and MAO AB KO mice of the indicated ages. Values are the mean and SEM $\left(n=3-4\right.$ mice). ${ }^{*} p<0.05$, ${ }^{* *} p<0.01$. $D$, Levels of MAO A and MAOB activities in neurospheres cultured from WT and MAO AB KO mice of the indicated ages (E12.5, E15.5, and P2). Note that cultured NS exhibit MAO A, but not MAO B activity, and MAO A activity significantly increases as development proceeds. $E$, Levels of MAO A activity in E17.5 neurospheres measured $24 \mathrm{~h}$ after treatment with the indicated concentrations of clorgyline (an inhibitor of MAO A). $\boldsymbol{F}, \boldsymbol{G}$, Clorgyline administration did not significantly alter the diameter $(\boldsymbol{F})$ or number $(\boldsymbol{G})$ of neurospheres in cultures established from P2 cortical tissue. $\boldsymbol{H}$, Low concentrations of serotonin (10 and $100 \mathrm{ng} / \mathrm{ml}$ ) stimulate neurosphere formation in P2 cultures from WT mice, but not in cultures from MAO AB KO mice. Values are the mean and SEM ( $n=3-4$ mice). ${ }^{* *} p<0.01$ compared with the value for cultures not exposed to serotonin.

2007; Vitalis et al., 2007). These studies concluded that reduced levels of serotonin and/or blocking 5-HT receptors reduce neurogenesis in adult animals. Intriguingly, we observed that 5-HT levels in MAO AB KO mice during brain development exhibit a distinct pattern, with a large surge during late embryonic and early postnatal stages; however, this increase in serotonin levels is associated with a reduction in NSC numbers. Furthermore, using PCPA to suppress the serotonin production from mid-gestational stage (E14.5-E19.5) (Fig. 7) in MAO AB mice restored the number of TBR2 + cells in the SVZ of dorsal telencephalon to normal levels. Although DA has been shown to affect progenitor cell proliferation in the embryonic telencephalon (Ohtani et al., 2003; Zhang et al., 2005), our HPLC data showed that there were no differences in DA levels between WT and MAO AB KO mice at any developmental stage. Collectively, our findings suggest that 5-HT, not other MAO A and B substrates (NE, DA, or PEA) are responsible for the reduction of IPC. In contrast, we found that
NSC isolated from the telencephalon of MAO AB KO mice at late embryonic and early postnatal stages exhibited reduced neurosphere formation and size and did not respond positively to serotonin compared with NSC from age-matched wild-type mice (Fig. 6). In contrast, no differences between MAO AB KO and wild-type neurospheres were observed when the cultures were established from younger embryos (E14.5 or younger). One explanation of these results is that the reduction of IPC in MAO AB $\mathrm{KO}$ mice compared with WT mice in vivo is due to an abrogated response of NSC to chronically elevated levels of serotonin. MAO deficiency and the persistent exposure to excessive levels of serotonin during a critical period of cortical development could result in a long-lasting alteration of IPC self-renewal properties and impaired responsiveness of neural progenitors to serotonin. During brain development, increased 5-HT levels could have many secondary effects, including downregulation of 5-HT receptors (Shih et al., 1999) and aberrant growth of dendrites (Haydon et 


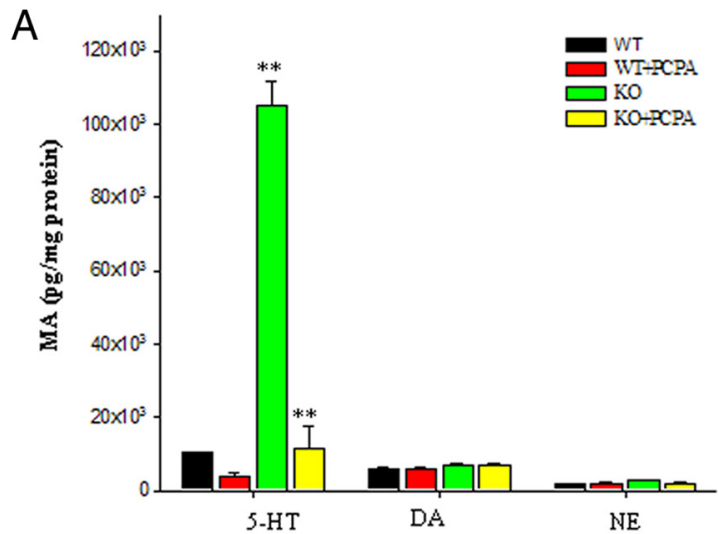

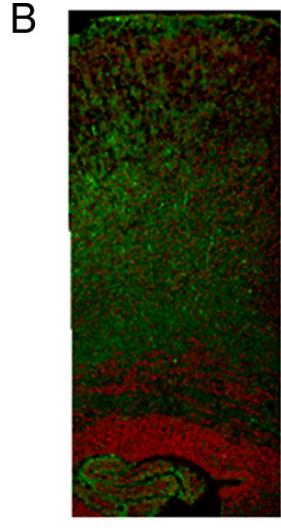

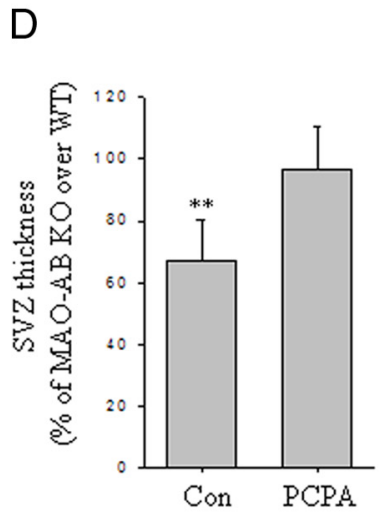

WT

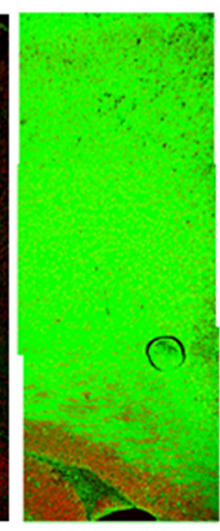

MAO-AB KO

E

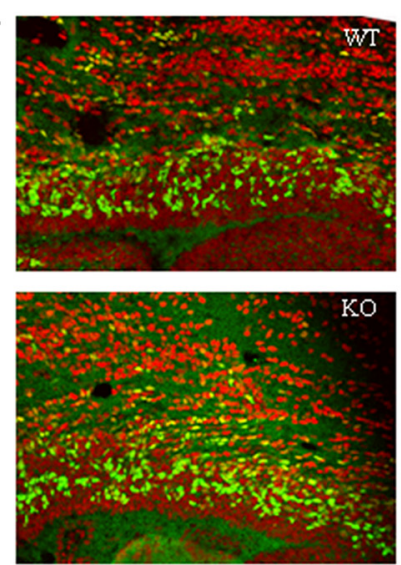

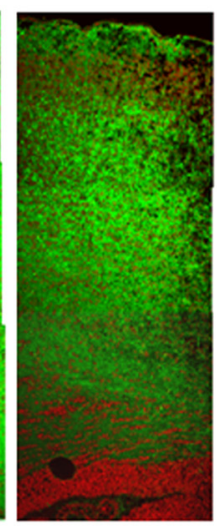

MAO-AB KO+PCPA
C
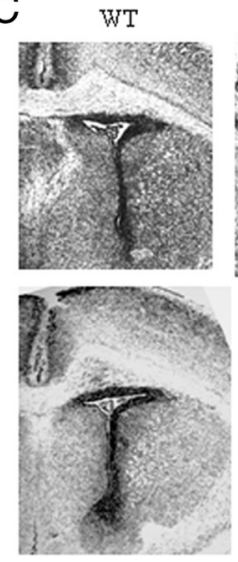

$\mathrm{KO}$

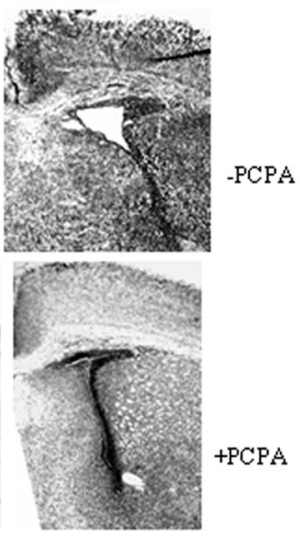

Figure 7. Blocking the serotonin surge in the telencephalon of MAO AB KO mice during late embryonic and early postnatal development restores NSC proliferation and cortical thickness to normal levels. $A$, Serotonin levels in the cortex of P1 WT mice that had developed in pregnant dams treated with vehicle ( - ) or the serotonin synthesis inhibitor PCPA ( + ) from E14.5 to E18.5. Note that PCPA treatment completely blocked the serotonin surge in MAO AB KO mice. The DA and NE level is very low at this stage and not affected by treatment of PCPA. $\boldsymbol{B}$, Images showing serotonin immunoreactivity (green) in the frontal cortex of WT mice and MAO AB KO mice that had been treated with vehicle or PCPA during late embryonic development. Note that serotonin immunoreactivity was markedly elevated in the cortex of MAO AB mice compared with WT mice, and that PCPA treatment greatly decreased the serotonin immunoreactivity. C, Representative images of Niss staining of a section through the frontal cortex of P1-P2 WT mice, and MAO AB KO mice that had been treated with either vehicle or PCPA during late embryonic development. The thickness reduction of SVZ in both telencephalon and striatum region is apparently restored by PCPA treatment in MAO AB KO mice. D, Quantification of SVZ thickness in P1-P2 WT mice and MAO AB KO mice that had been treated with vehicle or PCPA during embryonic development. Values for vehicle treated control mice (Con) and PCPA-treated mice are expressed as a percentage of the cortical thickness value for WT mice (mean and SEM; $n=4-5$ mice). $E$, Images showing TBR2 immunoreactivity (green) and cell nuclei stained with PI (red) in brain sections from a P2 WT mouse and a P2 MA0 AB K0 mouse that had been treated with PCPA during late embryonic development. $\boldsymbol{F}$, Values for numbers of TBR2 ${ }^{+}$cells in the SVZ of P2 WT mice and P2 MA0 AB K0 mouse that had been treated with PCPA during late embryonic development. Values are the mean and SEM ( $n=4-5$ mice).

al., 1987). Receptors for DA, 5-HT, and NE were previously reported to be expressed in early brain development, and some MA receptor subtypes are present in the VZ and SVZ (Johnson and Heinemann, 1995; Lidow and Rakic, 1995; Tecott et al., 1995; Fishburn et al., 1996; Jung and Bennett, 1996; Diaz et al., 1997; Wang and Lidow, 1997; Wang et al., 1997; Bonnin et al., 2006). Consistent with notion, we found that 5-HT1A is expressed in both E12.5 and P2 NS, with reduction in P2 NS but not in E12.5 NS, from MAO AB KO mice compared with NS from WT mice (supplemental Fig. S3, available at www.jneurosci.org as supplemental material). Previous studies in which serotonin levels were increased or decreased and/or depleted acutely provided evidence that serotonin can stimulate NSC proliferation (Banasr et al., 2004). Our data from studies of MAO AB KO mice suggest that sustained elevation of serotonin levels is detrimental for IPC proliferation during cerebral cortical development in the late embryonic and early postnatal periods. Therefore, MAO AB KO mice provide a unique model to further study the molecular mechanisms of NSC proliferation regulated by $5-\mathrm{HT}$.

As important components of stem-cell niches, differentiated cells control the behavior of adjacent stem cells by generating intercellular signals (Temple, 2001; Lathia et al., 2007). Stem-cell niches include the physical engagement and/or signaling interactions of the cell membrane with tethering molecules on neighboring cells or integral membrane proteins that form intercellular gap junction channels (Cheng et al., 2004). Notch and notch ligands, cell adhesion molecules, growth factors, cytokines, neurotransmitters, and nitric oxide are examples of prominent signaling molecules within the NSC niche (Cameron et al., 1998; Cheng et al., 2003; Yoon and Gaiano, 2005, Lathia et al., 2008; Bauer, 2009; Loulier et al., 2009). Our study provides novel insight into how monoaminergic signals can regulate brain development by influencing the proliferation of NSC. The time window during which MAO AB deficiency altered neural progenitor behaviors and telencephalic development in the present study coincides with the time period when serotonin-releasing axonal growth cones innervate the telencephalon (Ivgy-May et al., 1994). We found that there was a large increase in levels of serotonin in the telencephalon from the late embryonic to early postnatal time period in $\mathrm{MAO} \mathrm{AB} \mathrm{KO}$ mice, which coincides with the time window when IPC proliferation is impaired in these mice compared with wildtype control mice. Previous studies in which serotonin signaling 
was manipulated using pharmacological agents suggested roles for serotonin in tissue morphogenesis early in embryonic development in multiple tissues, including the nervous system and heart (Nebigil and Maroteaux, 2001; Luo et al., 2003). In contrast, no major abnormalities in the nervous or cardiovascular systems are evident in adult MAO AB knock-out mice. However, adult $\mathrm{MAO} \mathrm{AB}$-deficient mice do exhibit altered functional regulation of the heart, characterized by a relative increase in parasympathetic tone (Holschneider et al., 2002), and also exhibit anxietylike behavioral alterations (Chen et al., 2004). Studies of patients with depression and the mechanism of action of antidepressants suggest that too little serotonin can suppress adult neurogenesis and cause anxiety and depression (Boldrini et al., 2009). On the other hand, our findings suggest that MAO AB deficiency, through disrupting the serotonin degradation, can impair neurogenesis during a critical period of brain development, which could contribute to enhanced anxiety-like behavior during adult life.

During brain development, IPC arise from radial glial cells at the onset of neurogenesis (Haubensak et al., 2004; Miyata et al., 2004; Noctor et al., 2004). They undergo non-surface symmetrical divisions in either the basal portion of the VZ or the SVZ to produce two neuronal daughters, thereby potentially doubling the number of generated neurons. Consistent with previous reports (Englund et al., 2005; Noctor et al., 2008), we observed that IPCs are located on the top of the VZ with some intermingled with VZ cells, and that the proportion of IPC in dorsal telencephalon germinal zone is gradually increased in contrast to the corresponding diminution of $\mathrm{VZ}$ cells. MAO AB KO mice provide a unique model in which a significant reduction of IPC in SVZ occurs beginning in late embryonic stages (E17.5-P2), but not at early and mid-gestational stages (E12.5-E14.5). The reasons why IPC are specifically impaired in MAO AB KO mice may include the fact that IPC in the SVZ are located adjacent to the differentiated layer of the intermediate zone (IZ), where serotonergic fibers innervate the cerebral cortex (Wallace and Lauder, 1983). Indeed, serotonergic afferents arrive in the cerebral cortex around mid-gestation when IPC start to be the predominant cell type in the germinal zone. Consistent with the latter mechanism, serotonin immunostaining in E17.5 WT and MAO AB KO demonstrated that there are relatively large amounts of serotonin in the cortical plate (CP) and IZ with little serotonin in the germinal zone. Serotonin levels are increased dramatically in CP and IZ of MAO AB-deficient mice. The fate(s) of IPC progeny is not clear. Previous studies have shown that the progenies of IPC migrate into the cortical plate (Noctor et al., 2004) where they differentiate into pyramidal cells (Wu et al., 2005; Kowalczyk et al., 2009). Recent studies (Tabata et al., 2009) strongly suggested that neurons arising from IPC migrate into cortical plate to contribute to the total number of layers II/III neurons. Therefore, MAO AB KO mice could provide a unique model to understand the development of IPC and how MAOs and MAs regulate developmental and adult neuroplasticity and behavior.

\section{References}

Angevine JB Jr, Bodian D, Coulombre AJ, Edds MV Jr, Hamburger V, Jacobson M, Lyser KM, Prestige MC, Sidman RL, Varon S, Weiss PA (1970) Embryonic vertebrate central nervous system: revised terminology. Anat Rec 166:257-261.

Bach AW, Lan NC, Johnson DL, Abell CW, Bembenek ME, Kwan SW, Seeburg PH, Shih JC (1988) cDNA cloning of human liver monoamine oxidase A and B: molecular basis of differences in enzymatic properties. Proc Natl Acad Sci U S A 85:4934-4938.

Banasr M, Hery M, Brezun JM, Daszuta A (2001) Serotonin mediates oes- trogen stimulation of cell proliferation in the adult dentate gyrus. Eur J Neurosci 14:1417-1424.

Banasr M, Hery M, Printemps R, Daszuta A (2004) Serotonin-induced increases in adult cell proliferation and neurogenesis are mediated through different and common 5-HT receptor subtypes in the dentate gyrus and the subventricular zone. Neuropsychopharmacology 29:450-460.

Bauer S (2009) Cytokine control of adult neural stem cells. Ann N Y Acad Sci 1153:48-56.

Berger-Sweeney J, Hohmann CF (1997) Behavioral consequences of abnormal cortical development: insights into developmental disabilities. Behav Brain Res 86: 121-142.

Boldrini M, Underwood MD, Hen R, Rosoklija GB, Dwork AJ, John Mann J, Arango V (2009) Antidepressants increase neural progenitor cells in the human hippocampus. Neuropsychopharmacology 34: 2376-2389.

Bonnin A, Peng W, Hewlett W, Levitt P (2006) Expression mapping of 5-HT1 serotonin receptor subtypes during fetal and early postnatal mouse forebrain development. Neuroscience 141:781-794.

Brezun JM, Daszuta A (1999) Depletion in serotonin decreases neurogenesis in the dentate gyrus and the subventricular zone of adult rats. Neuroscience 89:999-1002.

Bulfone A, Martinez S, Marigo V, Campanella M, Basile A, Quaderi N, Gattuso C, Rubenstein JL, Ballabio A (1999) Expression pattern of the Tbr2 (Eomesodermin) gene during mouse and chick brain development. Mech Dev 84:133-138.

Cai J, Wu Y, Mirua T, Pierce JL, Lucero MT, Albertine KH, Spangrude GJ, Rao MS (2002) Properties of a fetal multipotent neural stem cell (NEP cell). Dev Biol 251:221-240.

Cameron HA, Hazel TG, McKay RD (1998) Regulation of neurogenesis by growth factors and neurotransmitters. J Neurobiol 36:287-306.

Chen K, Holschneider DP, Wu W, Rebrin I, Shih JC (2004) A spontaneous point mutation produces monoamine oxidase A/B knock-out mice with greatly elevated monoamines and anxiety-like behavior. J Biol Chem 279:39645-39652.

Cheng A, Wang S, Cai J, Rao MS, Mattson MP (2003) Nitric oxide acts in a positive feedback loop with BDNF to regulate neural progenitor cell proliferation and differentiation in the mammalian brain. Dev Biol 258:319-333.

Cheng A, Tang H, Cai J, Zhu M, Zhang X, Rao M, Mattson MP (2004) Gap junctional communication is required to maintain mouse cortical neural progenitor cells in a proliferative state. Dev Biol 272:203-216.

Cheng A, Coksaygan T, Tang H, Khatri R, Balice-Gordon RJ, Rao MS, Mattson MP (2007) Truncated tyrosine kinase B brain-derived neurotrophic factor receptor directs cortical neural stem cells to a glial cell fate by a novel signaling mechanism. J Neurochem 100:1515-1530.

Corbin JG, Gaiano N, Juliano SL, Poluch S, Stancik E, Haydar TF (2008) Regulation of neural progenitor cell development in the nervous system. J Neurochem 106:2272-2287.

Coyle JT, Molliver ME (1977) Major innervation of newborn rat cortex by monoaminergic neurons. Science 196:444-447.

Diaz J, Ridray S, Mignon V, Griffon N, Schwartz JC, Sokoloff P (1997) Selective expression of dopamine $\mathrm{D} 3$ receptor $\mathrm{mRNA}$ in proliferative zones during embryonic development of the rat brain. J Neurosci 17:4282-4292.

Dori I, Dinopoulos A, Blue ME, Parnavelas JG (1996) Regional differences in the ontogeny of the serotonergic projection to the cerebral cortex. Exp Neurol 138:1-14.

Englund C, Fink A, Lau C, Pham D, Daza RA, Bulfone A, Kowalczyk T, Hevner RF (2005) Pax6, Tbr2, and Tbr1 are expressed sequentially by radial glia, intermediate progenitor cells, and postmitotic neurons in developing neocortex. J Neurosci 25:247-251.

Fishburn CS, Bedford M, Lonai P, Fuchs S (1996) Early expression of D3 dopamine receptors in murine embryonic development. FEBS Lett 381:257-261.

Geha RM, Rebrin I, Chen K, Shih JC (2001) Substrate and inhibitor specificities for human monoamine oxidase A and B are influenced by a single amino acid. J Biol Chem 276:9877-9882.

Götz M, Huttner WB (2005) The cell biology of neurogenesis. Nat Rev Mol Cell Biol 6:777-788.

Gould E (1999) Serotonin and hippocampal neurogenesis. Neuropsychopharmacology 21:46S-51S.

Haubensak W, Attardo A, Denk W, Huttner WB (2004) Neurons arise in 
the basal neuroepithelium of the early mammalian telencephalon: a major site of neurogenesis. Proc Natl Acad Sci U S A 101:3196-3201.

Haydon PG, McCobb DP, Kater SB (1987) Regulation of neurite outgrowth, growth cone motility, and electrical synaptogenesis by serotonin. J Neurobiol 18:197-215.

Holschneider DP, Scremin OU, Chialvo DR, Chen K, Shih JC (2002) Heart rate dynamics in monoamine oxidase-A- and -B-deficient mice. Am J Physiol Heart Circ Physiol 282:H1751-H1759.

Iatropoulos MJ, Williams GM (1996) Proliferation markers. Exp Toxicol Pathol 48:175-181.

Ivgy-May N, Tamir H, Gershon MD (1994) Synaptic properties of serotonergic growth cones in developing rat brain. J Neurosci 14:1011-1029.

Johnson DS, Heinemann SF (1995) Embryonic expression of the 5-HT3 receptor subunit, 5-HT3R-A, in the rat: an in situ hybridization study. Mol Cell Neurosci 6:122-138.

Jung AB, Bennett JP Jr (1996) Development of striatal dopaminergic function. II. Dopaminergic regulation of transcription of the immediate early gene zif268 and of D1 (D1a) and D2 (D2a) receptors during pre- and postnatal development. Brain Res Dev Brain Res 94:121-132.

Kowalczyk T, Pontious A, Englund C, Daza RA, Bedogni F, Hodge R, Attardo A, Bell C, Huttner WB, Hevner RF (2009) Intermediate neuronal progenitors (basal progenitors) produce pyramidal-projection neurons for all layers of cerebral cortex. Cereb Cortex 19:2439-2450.

Krasnova IN, Betts ES, Dada A, Jefferson A, Ladenheim B, Becker KG, Cadet JL, Hohmann CF (2007) Neonatal dopamine depletion induces changes in morphogenesis and gene expression in the developing cortex. Neurotox Res 11:107-130.

Ladenheim B, Krasnova IN, Deng X, Oyler JM, Polettini A, Moran TH, Huestis MA, Cadet JL (2000) Methamphetamine-induced neurotoxicity is attenuated in transgenic mice with a null mutation for interleukin-6. Mol Pharmacol 58:1247-1256.

Lathia JD, Rao MS, Mattson MP, Ffrench-Constant C (2007) The microenvironment of the embryonic neural stem cell: lessons from adult niches? Dev Dyn 236:3267-3282.

Lathia JD, Okun E, Tang SC, Griffioen K, Cheng A, Mughal MR, Laryea G, Selvaraj PK, ffrench-Constant C, Magnus T, Arumugam TV, Mattson MP (2008) Toll-like receptor 3 is a negative regulator of embryonic neural progenitor cell proliferation. J Neurosci 28:13978-13984.

Lau WM, Qiu G, Helmeste DM, Lee TM, Tang SW, So KF, Tang SW (2007) Corticosteroid decreases subventricular zone cell proliferation, which could be reversed by paroxetine. Restor Neurol Neurosci 25:17-23.

Lauder JM (1993) Neurotransmitters as growth regulatory signals: role of receptors and second messengers. Trends Neurosci 16:233-240.

Lauder JM, Bloom FE (1974) Ontogeny of monoamine neurons in the locus coeruleus, Raphe nuclei and substantia nigra of the rat. I. Cell differentiation. J Comp Neurol 155:469-481.

Levitt P, Rakic P (1982) The time of genesis, embryonic origin and differentiation of the brain stem monoamine neurons in the rhesus monkey. Brain Res 256:35-57.

Levitt P, Harvey JA, Friedman E, Simansky K, Murphy EH (1997) New evidence for neurotransmitter influences on brain development. Trends Neurosci 20:269-274.

Lidov HG, Grzanna R, Molliver ME (1980) The serotonin innervation of the cerebral cortex in the rat: an immunohistochemical analysis. Neuroscience 5:207-227.

Lidow MS, Rakic P (1995) Neurotransmitter receptors in the proliferative zones of developing primate occipital lobe. J Comp Neurol 360:393-402.

Loulier K, Lathia JD, Marthiens V, Relucio J, Mughal MR, Tang SC, Coksaygan T, Hall PE, Chigurupati S, Patton B, Colognato H, Rao MS, Mattson MP, Haydar TF, ffrench-Constant C (2009) Betal integrin maintains integrity of the embryonic neocortical stem cell niche. PLoS Biol 7:e1000176.

Luo X, Persico AM, Lauder JM (2003) Serotonergic regulation of somatosensory cortical development: lessons from genetic mouse models. Dev Neurosci 25:173-183.

Martin B, Pearson M, Kebejian L, Golden E, Keselman A, Bender M, Carlson O, Egan J, Ladenheim B, Cadet JL, Becker KG, Wood W, Duffy K, Vinayakumar P, Maudsley S, Mattson MP (2007) Sex-dependent metabolic, neuroendocrine, and cognitive responses to dietary energy restriction and excess. Endocrinology 148:4318-4333.
Miyata T, Kawaguchi A, Saito K, Kawano M, Muto T, Ogawa M (2004) Asymmetric production of surface-dividing and non-surface-dividing cortical progenitor cells. Development 131:3133-3145.

Nebigil CG, Maroteaux L (2001) A novel role for serotonin in heart. Trends Cardiovasc Med 11:329-335.

Noctor SC, Martínez-Cerdeño V, Ivic L, Kriegstein AR (2004) Cortical neurons arise in symmetric and asymmetric division zones and migrate through specific phases. Nat Neurosci 7:136-144.

Noctor SC, Martínez-Cerdeño V, Kriegstein AR (2008) Distinct behaviors of neural stem and progenitor cells underlie cortical neurogenesis. J Comp Neurol 508:28-44.

Ohtani N, Goto T, Waeber C, Bhide PG (2003) Dopamine modulates cell cycle in the lateral ganglionic eminence. J Neurosci 23:2840-2850.

Santarelli L, Saxe M, Gross C, Surget A, Battaglia F, Dulawa S, Weisstaub N, Lee J, Duman R, Arancio O, Belzung C, Hen R (2003) Requirement of hippocampal neurogenesis for the behavioral effects of antidepressants. Science 301:805-809.

Schlumpf M, Shoemaker WJ, Bloom FE (1980) Innervation of embryonic rat cerebral cortex by catecholamine-containing fibers. J Comp Neurol 192:361-376.

Shih JC, Ridd MJ, Chen K, Meehan WP, Kung MP, Seif I, De Maeyer E (1999) Ketanserin and tetrabenazine abolish aggression in mice lacking monoamine oxidase A. Brain Res 835:104-112.

Tabata H, Kanatani S, Nakajima K (2009) Differences of migratory behavior between direct progeny of apical progenitors and basal progenitors in the developing cerebral cortex. Cereb Cortex 19:2092-2105.

Takahashi T, Nowakowski RS, Caviness VS Jr (1992) BUdR as an S-phase marker for quantitative studies of cytokinetic behaviour in the murine cerebral ventricular zone. J Neurocytol 21:185-197.

Tecott L, Shtrom S, Julius D (1995) Expression of a serotonin-gated ion channel in embryonic neural and nonneural tissues. Mol Cell Neurosci 6:43-55.

Temple S (2001) The development of neural stem cells. Nature 414: $112-117$.

Vergé D, Calas A (2000) Serotoninergic neurons and serotonin receptors: gains from cytochemical approaches. J Chem Neuroanat 18:41-56

Vitalis T, Cases O, Passemard S, Callebert J, Parnavelas JG (2007) Embryonic depletion of serotonin affects cortical development. Eur J Neurosci 26:331-344.

Wallace JA, Lauder JM (1983) Development of the serotonergic system in the rat embryo: an immunocytochemical study. Brain Res Bull 10:459479 .

Wang F, Lidow MS (1997) Alpha 2A-adrenergic receptors are expressed by diverse cell types in the fetal primate cerebral wall. J Comp Neurol 378:493-507.

Wang F, Bergson C, Howard RL, Lidow MS (1997) Differential expression of D1 and D5 dopamine receptors in the fetal primate cerebral wall. Cereb Cortex 7:711-721.

Wu SX, Goebbels S, Nakamura K, Nakamura K, Kometani K, Minato N, Kaneko T, Nave KA, Tamamaki N (2005) Pyramidal neurons of upper cortical layers generated by NEX-positive progenitor cells in the subventricular zone. Proc Natl Acad Sci U S A 102:17172-17177.

Yoon K, Gaiano N (2005) Notch signaling in the mammalian central nervous system: insights from mouse mutants. Nat Neurosci 8:709-715.

Zappone MV, Galli R, Catena R, Meani N, De Biasi S, Mattei E, Tiveron C, Vescovi AL, Lovell-Badge R, Ottolenghi S, Nicolis SK (2000) Sox2 regulatory sequences direct expression of a (beta)-geo transgene to telencephalic neural stem cells and precursors of the mouse embryo, revealing regionalization of gene expression in CNS stem cells. Development 127:2367-2382.

Zecevic N, Verney C (1995) Development of the catecholamine neurons in human embryos and fetuses, with special emphasis on the innervation of the cerebral cortex. J Comp Neurol 351:509-535.

Zhang L, Bai J, Undie AS, Bergson C, Lidow MS (2005) D1 dopamine receptor regulation of the levels of the cell-cycle-controlling proteins, cyclin D, P27 and Raf-1, in cerebral cortical precursor cells is mediated through cAMP-independent pathways. Cereb Cortex 15:74-84. 